\title{
Mycosis Fungoides and Sezary Syndrome B0 TNM Finding v7
}

National Cancer Institute

\section{Source}

National Cancer Institute. Mycosis Fungoides and Sezary Syndrome BO TNM Finding v7.

NCI Thesaurus. Code C88250.

Absence of significant blood involvement: $5 \%$ or less of peripheral blood lymphocytes are atypical (Sezary cells). Note: for blood, Sezary cells are defined as lymphocytes with hyperconvoluted cerebriform nuclei. If Sezary cells are not able to be used to determine tumor burden for B2, then one of the following modified ISCL criteria along with a positive clonal rearrangement of the TCR may be used instead: (1) expanded CD4+ or CD3+ cells with CD4/CD8 ratio of 10 or more, (2) expanded CD4+ cells with abnormal immunophenotype including loss of CD7 or CD26. (from AJCC 7th Ed.) 